\title{
Parasite Infections in Danish Trout Farms
}

\author{
By K. Buchmann, A. Uldal and H.C. K. Lyholt
}

Department of Veterinary Microbiology, Section of Fish Diseases, The Royal Veterinary and Agricultural University, Frederiksberg, Denmark.

\begin{abstract}
Buchmann, K., A. Uldal and H. Lyholt. Parasite infections in Danish trout farms. Acta vet. scand. 1995, 36, 283-298. - Samples from 5 Danish freshwater trout farms rearing rainbow trout (Oncorhynchus mykiss) were examined for parasite infections from October 1993 until November 1994 and recorded parasites are listed. In addition, results from an examination of a mariculture net cage system are presented as well. A total of 10 metazoan and 10 protozoan parasites were recorded. The metazoans included $G y$ rodactylus derjavini, Gyrodactylus salaris, Eubothrium crassum, Triaenophorus nodulosus, Proteocephalus sp., Diplostomum spathaceum, Tylodelphus clavata and Argulus foliaceus from the freshwater farms. The protozoans Hexamita salmonis, Ichthyobodo necator, Ichthyophthirius multifiliis, Apiosoma sp., Epistylis sp., Trichodina nigra, T. mutabilis, T. fultoni, Trichodinella epizootica, and an Ichthyophonus like intestinal parasite were also detected in the freshwater trout farms. Based on lectin binding studies, few fish were found positive for the myxosporean parasite PKX although no clinical cases were reported. In the mariculture system, Lepeophtheirus salmonis and Caligus elongatus were found.
\end{abstract}

Rainbow trout; Oncorhynchus mykiss; metazoans; protozoans; aquaculture.

\section{Introduction}

The Danish production of rainbow trout $(\mathrm{On}$ corhynchus mykiss) has increased significantly during the last century from zero production in 1890 to a total annual output of 42.000 metric tonnes (35.000 tonnes in freshwater and 7.000 tonnes in sea water) in 1994. In order to optimize environmental and economical aspects of this aquacultural branch, a research programme was implemented in 1993. As a part of this programme we have monitored the parasite infections in selected freshwater trout farms during 1 year. The rainbow trout is the most important farmed salmonid on world basis and has been transplanted into a large variety of habitats. This has resulted in the recording of more than 160 different metazoan parasites (Buchmann et al.
1995) and more than 23 protozoan species (Lom \& Dykova 1992) from this host. The evident importance of parasite infections in cultivated salmonids has resulted in a range of investigations on parasites of these fishes. Thus lists of parasites from salmonid farms and hatcheries have previously been published (Zitnan \& Cankovic 1970, Hare \& Frantsi 1974, McGuigan \& Sommerville 1985). However, only a limited number of studies describing the annual variations of all parasite types in salmonid farms have been presented (Wootten \& Smith 1980, Rosengarten 1985, Poynton \& Bennett 1985). The present paper elucidates the annual variation of both metazoan and protozoan parasites from 5 trout farms in Denmark. 


\section{Materials and methods}

A sample of 5 freshwater trout farms, all situated in Jutland (western part of Denmark) with annual farm productions ranging from 50 tonnes to 100 tonnes, were selected (Table 1 a).

With few exceptions, monthly samples of 5 to 15 rainbow trouts (Oncorhynchus mykiss) (stages $0+$ or $1+$ ) were taken from each of the farms (Table $1 \mathrm{~b}$ ). The fishes were examined immediately or brought to the laboratory under refrigerated conditions and examined within 24h. All organs including fins, gills, skin, eyes, body cavity, heart, liver, spleen, kidney, swim bladder, oesophagus, stomach, pyloric caeca, and intestine were examined. The investigation was performed with a dissecting microscope (magnification 10-40 $\times$ ) and with smear or squash preparations in compound microscopes (magnification 100$1000 \times$ ). On few occasions, mucus scrapings from body surface and fins of spawners were examined for Gyrodactylus parasites.

Kidney smears on slides were prepared, fixed in phosphate buffered $4 \%$ formaldehyde $(\mathrm{pH}$ 7.1) and tested for the presence of lectin (GS1 from Griffonia simplicifolia Sigma L-3759) binding PKX bodies using a modification of the technique described by Hedrick et al. (1992). Briefly, after an initial 20 min incubation with blocking buffer (5\% BSA in TBS), biotinylated lectin in TBS ( $\mathrm{pH} 8.0)(20 \mu \mathrm{g} / \mathrm{ml})$ was added to the smears and reacted for 120 min. The smears were subsequently rinsed ( 5 $\mathrm{min}$ ) in TBS and incubated with avidin and biotin conjugated alkaline phosphatase in TBS with $2.5 \%$ BSA. Fast Red substrate system tablets (DAKO) (in Tris- $\mathrm{HCl}, \mathrm{pH}$ 8.2) was used as chromogen. Histology sections of kidney and spleen from an infected trout served as positive control. Positive parasite cells appeared bright red.

For identification of trichodinids, skin mucus smears containing parasites from trout were prepared on slides and incubated for $20 \mathrm{~min}$ with $2 \% \mathrm{AgNO}_{3}$, exposed to UV-light for 10 min and subsequently mounted in DePex lipofilic embedding medium.

Table 1 a. Trout farms examined for parasite infections from October 1993 until November 1994.

\begin{tabular}{llll}
\hline Farm & Water source & Production & Location \\
\hline 1 & Stream water/well water & Fry/fingerlings & Connected to other farms \\
2 & Stream water/well water & Fry/fingerlings/consumption fish & Isolated from other farms \\
3 & Lake water & Consumption fish & Connected to other farms \\
4 & Stream water/well water & Fingerlings/consumption fish & Connected to other farms \\
5 & Stream water & Fingerlings/consumption fish & Connected to several farms \\
\hline
\end{tabular}

Table $1 \mathrm{~b}$. Number of rainbow trouts from the 5 fish farms in the respective monthly samples.

\begin{tabular}{|c|c|c|c|c|c|c|c|c|c|c|c|c|c|c|}
\hline \multirow[b]{2}{*}{ Farm } & \multicolumn{3}{|c|}{1993} & \multicolumn{11}{|c|}{1994} \\
\hline & Oct & Nov & Dec & Jan & Feb & Mar & Apr & May & Jun & Jul & Aug & Sep & Oct & Nov \\
\hline 1 & 0 & 11 & 0 & 11 & 13 & 10 & 10 & 10 & 7 & 5 & 10 & 7 & 2 & 8 \\
\hline 2 & 0 & 0 & 0 & 0 & 5 & 10 & 10 & 10 & 10 & 9 & 6 & 6 & 7 & 5 \\
\hline 3 & 15 & 10 & 0 & 11 & 10 & 9 & 8 & 10 & 10 & 6 & 6 & 7 & 5 & 6 \\
\hline 4 & 0 & 0 & 10 & 0 & 5 & 10 & 0 & 5 & 10 & 5 & 5 & 7 & 7 & 6 \\
\hline 5 & 0 & 0 & 0 & 10 & 0 & 10 & 10 & 5 & 10 & 7 & 5 & 10 & 8 & 7 \\
\hline
\end{tabular}


Table 2. Parasites recorded in rainbow trout (Oncorhynchus mykiss) in 5 Danish farms from October 1993 until November 1994.

\begin{tabular}{|c|c|c|c|}
\hline Parasite & Authority & Location in host & Farm recorded \\
\hline \multicolumn{4}{|l|}{ Protozoans: } \\
\hline Hexamita salmonis & Moore 1923 & Intestine, pyloric caeca & $1,2,3,4,5$ \\
\hline Ichthyobodo necator & Henneguy 1884 & Gills, fins, skin & 1,4 \\
\hline Ichthyophthirius multifiliis & Fouquet 1876 & Fins and skin & $3,4,5$ \\
\hline Trichodina fultoni & Davis 1947 & Skin & 2 \\
\hline Trichodina nigra & Lom 1961 & Skin & $1,3,4,5$ \\
\hline Trichodina mutabilis & Kazubski \& Migala 1968 & Skin & $1,3,4,5$ \\
\hline Trichodinella epizootica & Raabe 1950 & Gills & 5 \\
\hline Apiosoma sp. & Blanchard 1885 & Fins and skin & $1,2,3,4,5$ \\
\hline Epistylis sp. & Ehrenberg 1830 & Fins and skin & $1,2,3,4,5$ \\
\hline PKX & Kidney & & $1,3,4,5$ \\
\hline \multicolumn{4}{|c|}{ Unknown taxonomic affiliation: } \\
\hline Ichthyophonus like organisn & & Anterior intestine & $1,2,3,4,5$ \\
\hline \multicolumn{4}{|l|}{ Metazoans: } \\
\hline \multicolumn{4}{|l|}{ Monogenea } \\
\hline Gyrodactylus derjavini & $\begin{array}{l}\text { Mikailov } 1975 \\
\text { (Malmberg et Malmberg } \\
\text { 1987) }\end{array}$ & Fins and skin & $1,3,4,5$ \\
\hline $\begin{array}{l}\text { Gyrodactylus salaris } \\
\text { Cestoda }\end{array}$ & \multicolumn{2}{|c|}{ Cestoda } & 1,5 \\
\hline Eubothrium crassum & Bloch 1979 & Juveniles in pyloric caeca and intestine & 3 \\
\hline Triaenophorus nodulosus & Pallas 1819 & Juveniles in body cavity & 3 \\
\hline $\begin{array}{l}\text { Proteocephalus sp. } \\
\text { Digenea }\end{array}$ & Weinland 1858 & Juvenile in intestine & 3 \\
\hline Diplostomum spathaceum & Rudolphi 1819 & Metacercaria in lens & 3,5 \\
\hline $\begin{array}{l}\text { Tylodelphus clavata } \\
\text { Crustacea }\end{array}$ & Nordmann 1832 & Metacercaria in vitreous humour & 3 \\
\hline Argulus foliaceus & Linnaeus 1758 & Skin & 3 \\
\hline Lepeophtheirus salmonis & Krøyer 1837 & Skin, mariculture only & \\
\hline Caligus elongatus & Nordmann 1832 & Skin, mariculture only & \\
\hline
\end{tabular}

Snails inhabiting the eyefluke infected trout farm were collected in the fish ponds in August 1994. They were placed at room temperature in $40 \mathrm{ml}$ vials containing $20 \mathrm{ml}$ pond water and monitored for cercarial shedding during the following $48 \mathrm{~h}$.

Crustacean ectoparasites from large specimens of rainbow trout $(>300 \mathrm{~g})$ originating from a high salinity mariculture net cage system were collected as well during August 1993.

Collected metazoan parasites were fixed in
$70 \%$ ethanol or $4 \%$ phosphate buffered formaldehyde and mounted in glycerine gelatine or ammonium picrate/glycerine (Malmberg 1957) for identification.

\section{Results}

The recorded parasites and their location in the hosts are presented in Table 2.

\section{Metazoan parasites}

Monogeneans. Only 2 species of monogeneans, Gyrodactylus derjavini (Fig. 1) and $G y$ - 


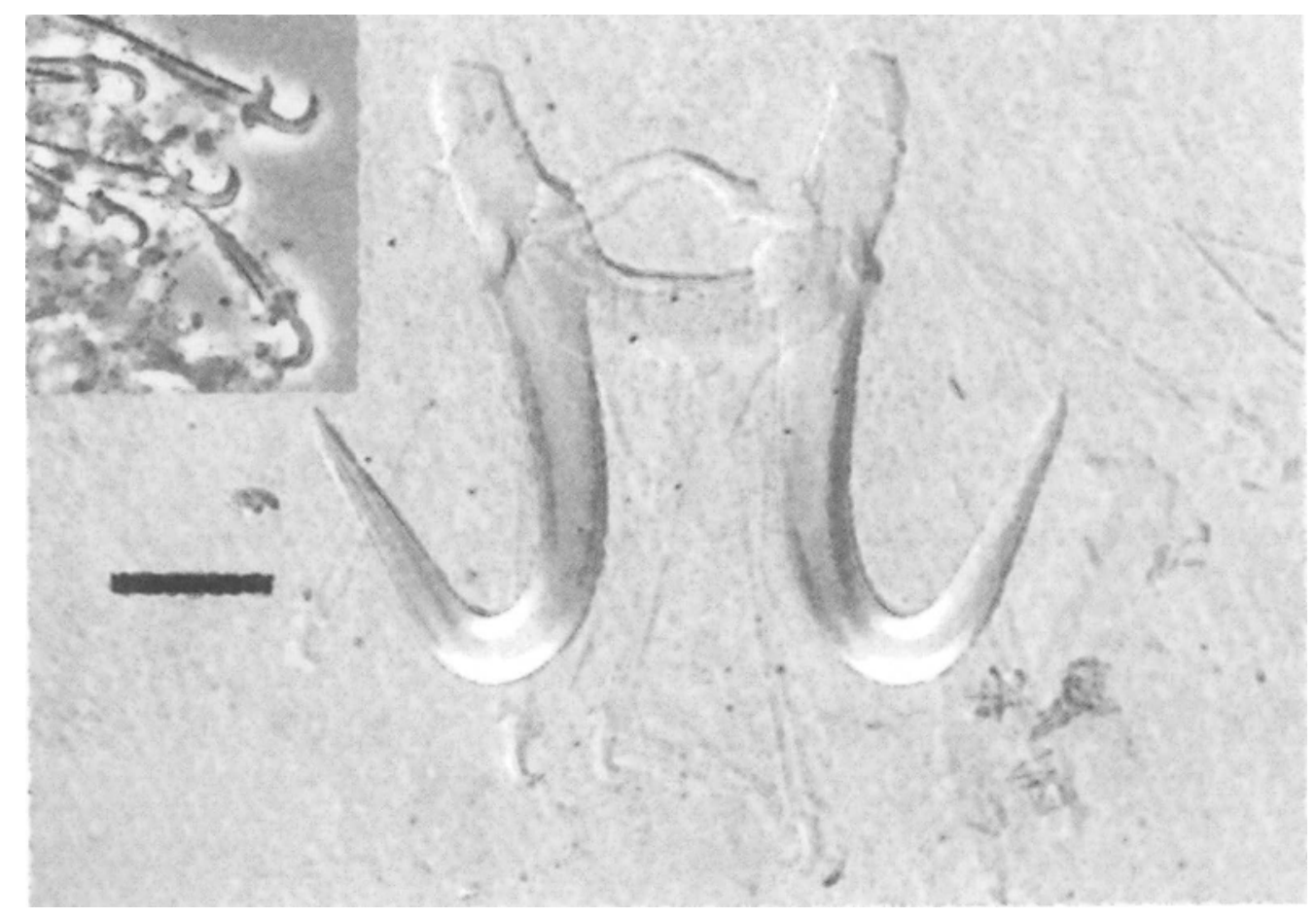

Figure 1. Gyrodactylus derjavini from a Danish rainbow trout (Farm 5, March 1994). Mounted in ammonium picrate/glycerine (Malmberg 1957). Scale bar: $10 \mu \mathrm{m}$. For recording of Figs. 1 and 2 a Leitz DMRBE microscope equipped with interference contrast with polarisation (anchors) or phase contrast (marginal hooklets) was used for magnification. A digital image processing and analysis system (Leica Q500 MC, Leica Cambridge Ltd, England) was applied for recording. (Courtesy of Dr. G. Malmberg, University of Stockholm).

rodactylus salaris (Fig. 2), were detected. However, the species recorded as $G$. derjavini in Farm 5 in August 1994 deviated slightly from the type specimen by having a slightly broader ventral bridge (G. Malmberg, personal comm.). One farm (Farm 2) was not found infected with gyrodactylids (fry and fingerlings). Two farms harboured $G$. derjavini only (Farm 3 and 4), and Farm 1 was exclusively infected with $G$. salaris except for November 1994 where both species were found. In Farm 5, the winter and early spring infection with $G$. salaris was replaced by $G$. derjavini in late May (Table 3).
Cestodes. Cestodes were found exclusively in the farm receiving water from a natural lake (Farm 3). Infection in autumn and winter (prevalence $0-40 \%$ ), intensity of infection 1 parasite per infected host) with Eubothrium crassum, Proteocephalus sp., Triaenophorus nodulosus, was found. Only single species infections were recorded.

Digeneans. No adult trematodes were found. Only metacercariae of the eye flukes Diplostomum spathaceum (located in the lens) and Tylodelphus clavata (located in the vitreous humour) were recorded. Both species occurred in Farm 3, whereas only a slight 


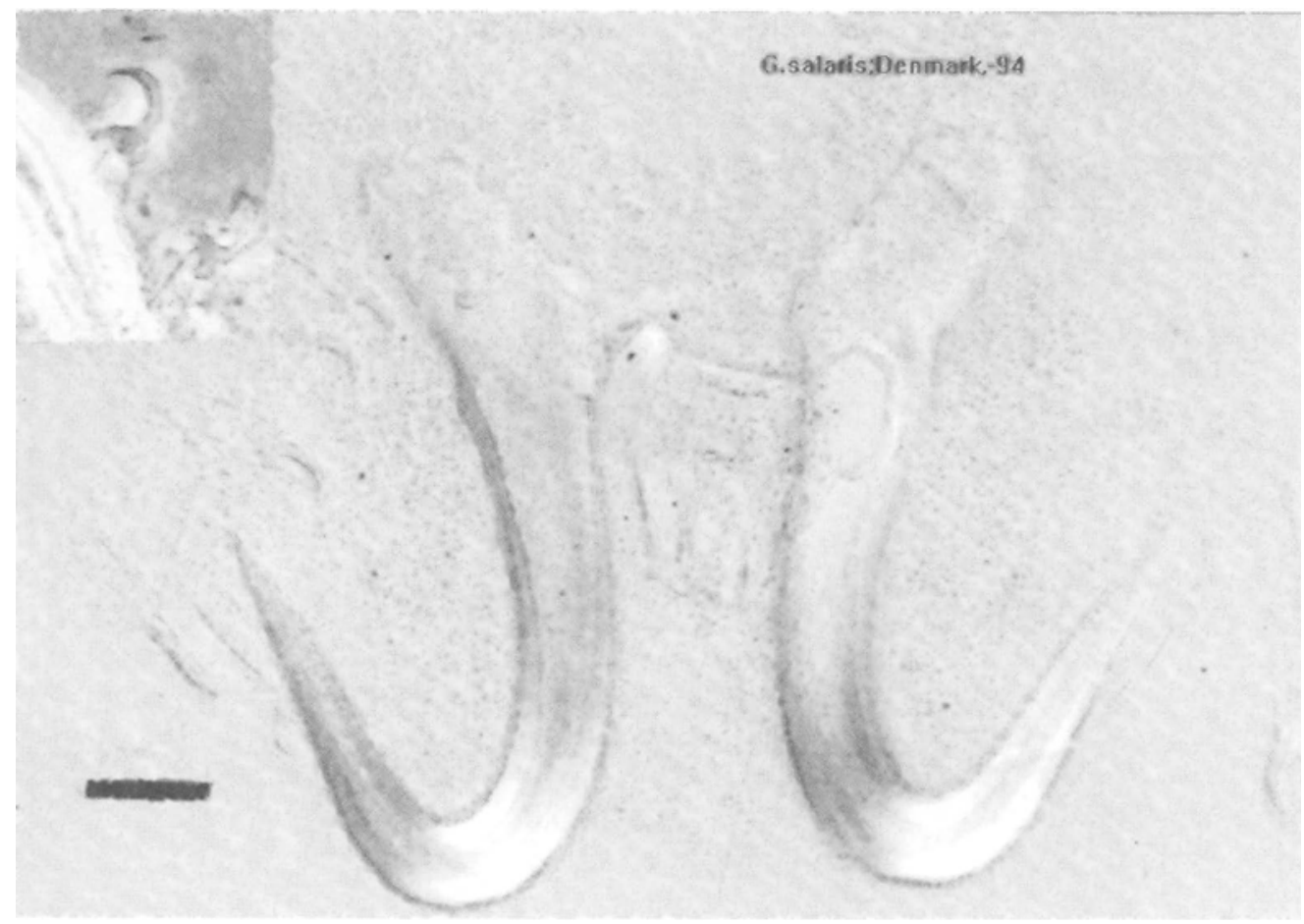

Figure 2. Gyrodactylus salaris from a Danish rainbow trout (Farm 5, May 1994). Scale bar: $10 \mu \mathrm{m}$.

D. spathaceum infection was found in Farm 5 ( $10 \%$ prevalence in January and $20 \%$ in April; no infection in the other months). In
Farm 3, a slight seasonal variation of the abundantly occurring $D$. spathaceum with lower prevalence from April until June was

Table 3. Occurrence of Gyrodactylus salaris and G. derjavini on rainbow trout in 4 Danish trout farms (Farm 1, 3, 4, 5) from October 1993 until November 1994. Farm 2 was not infected.

\begin{tabular}{|c|c|c|c|c|c|c|c|c|c|c|c|c|c|c|}
\hline & \multicolumn{3}{|c|}{1993} & \multicolumn{11}{|c|}{1994} \\
\hline & Oct & Nov & Dec & Jan & Feb & Mar & Apr & May & Jun & Jul & Aug & Sept & Oct & Nov \\
\hline $\begin{array}{l}\text { G. } \\
\text { salaris }\end{array}$ & & 1 & & 5 & & 5 & 5 & & $1^{*}$ & & $1^{*}$ & & & $1 *$ \\
\hline $\begin{array}{l}\text { G. de } \\
\text { rjavini }\end{array}$ & & & & & & & & 5 & 4 & & 5 & 3 & 3 & $\begin{array}{l}3 \\
1 *\end{array}$ \\
\hline
\end{tabular}

*: G. salaris was found on spawners only. 


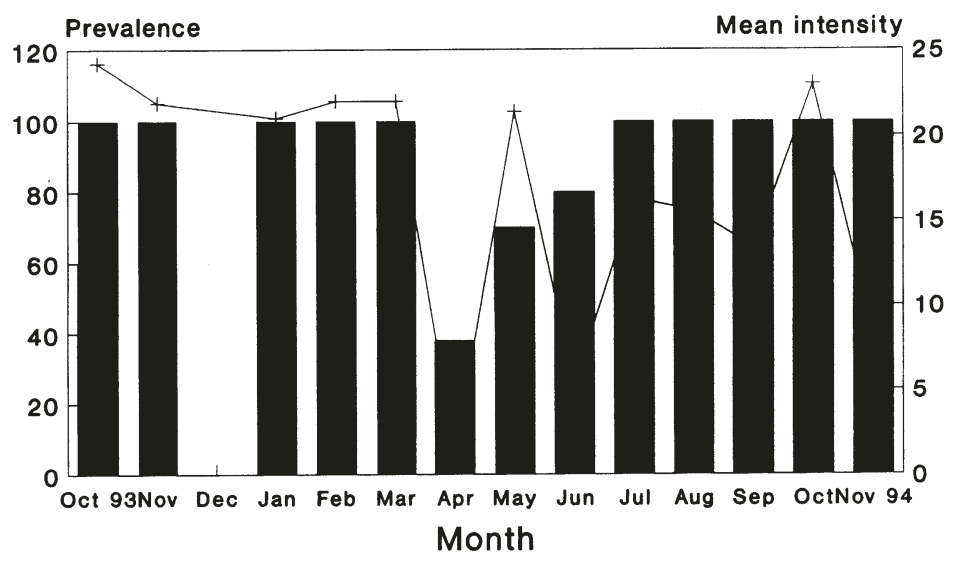

Prevalence + Intensity

Figure 3. Seasonal variation of prevalence (percentage of fish infected) and intensity of infection (mean number of parasites per infected host) of Diplostomum spathaceum in Farm 3 from October 1993 to November 1994.

registered (Fig. 3). Tylodelphus clavata infections affected between 10 and $90 \%$ of the trout throughout the year, but at very low intensities (1-5 parasites per infected host). The seasonal variation was irregular (Fig. 4). Of the collected pulmonate snails, 116 Lymnaea pereger and 35 L. stagnalis, some were shedding Diplostomum spathaceum cercariae (3.4\% and $2.9 \%$ respectively).

Nematodes. No nematodes were recorded. Acanthocephalans. No acanthocephalans were recorded.

Crustaceans. A low infection (1 trout infected with 1 parasite in August 1994) of the branchiuran Argulus foliaceus was detected exclusively in the farm supplied with natural lake water (Farm 3).

Large mariculture trouts were heavily infected with Lepeophtheirus salmonis and Caligus elongatus.

\section{Protozoan parasites}

Diplomonadid flagellates. The intestinal flagellate Hexamita salmonis occurred fre- quently and abundantly in hatchery fishes throughout the year (Fig. 5). Mostly small fish and fry (less than $7 \mathrm{~cm}$ body length) were infected, although a few larger fish harboured the infection as well. In heavily infected fry the entire length of the intestine from the pyloric region to the rectum was equally parasitized. In more lightly infected hosts, this flagellate occurred more abundantly in the anterior part of the intestine.

Kinetoplastid flagellates. The ectoparasitic flagellate Ichthyobodo necator occurred irregularly and rarely on the gills, fins, and skin of fry: $57 \%$ of Farm 1 fish were infected in September only and in Farm 4 only 20 and $12.5 \%$, in September and October respectively, of the examined fishes were infected with I. necator.

Myxosporeans. PKX. No gross pathological signs indicated PKD-infection on any occasion, but a few fish from 4 farms showed a positive lectin binding reaction for PKX parasites in the kidney from May until October. One farm (Farm 2) was free from infection, 


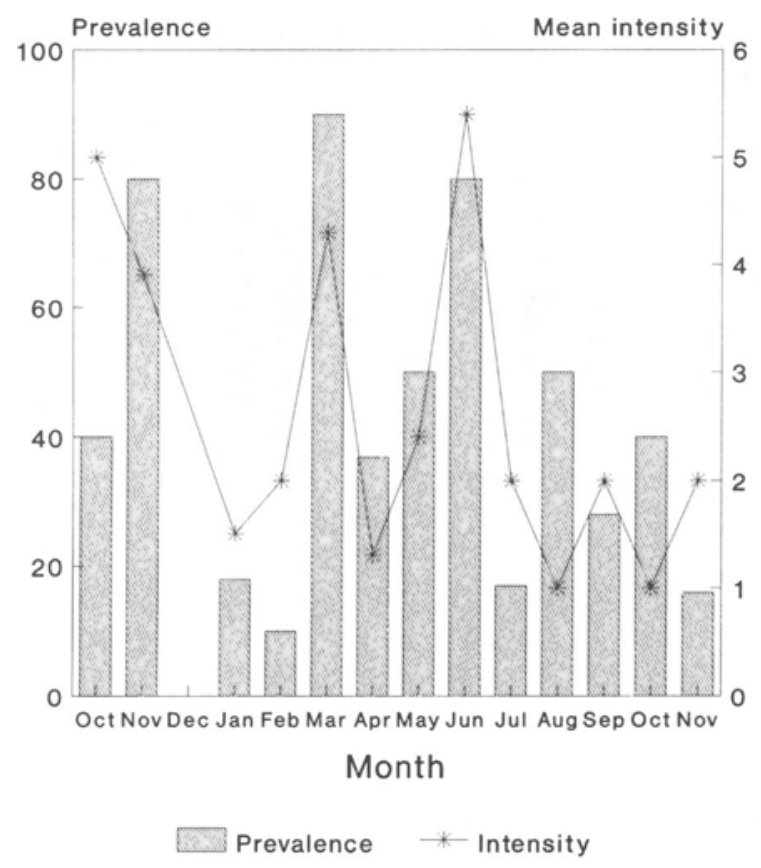

Figure 4. Seasonal variation of Tylodelphus clavata infections (prevalence and mean intensity) in Farm 3 from October 1993 until November 1994.

Farm 4 was found lectin-positive in May only, Farm 5 fish showed reaction in May, in July, and September, Farm 3 was positive in May, June, July, and Farm 1 in June only.

Ciliates. Ichthyophthirius multifiliis occurred irregularly on the fins and skin of fishes from 3 farms. No infection was found in Farms 1 and 2. In Farm 3, 14\% were infected in September only, in Farm 5, 25\% were infected in October, and in Farm 4 this ciliate was found in August (40\%), September (14\%) and October (14\%).

Apiosoma sp. and Epistylis sp. were found sporadically and infrequently on the skin and fins of trout throughout the year.

Ichthyophonus-like protistan. An intestinal fungus-like organism with an appearance as Ichthyophonus-stages (Fig. 6) described by
Okamoto et al. (1985) was found throughout the year in relatively low prevalences (Fig. 7). The organisms were located in the anterior intestinal wall or intestinal content, which often was of a yellowish jelly like consistence in infected fish.

Trichodina spp. occurred frequently but in low numbers on the trout skin thoughout the year (Fig. 8). T. nigra and T. mutabilis was found. In addition, in Farm 2 another species with a diameter of the adhesive disc of specimens stained with silver nitrate was measured to $74-80 \mu \mathrm{m}$, the number of denticles were 29 , and the number of radial pins per denticle blade was 14 . The center of the disc was unstained with argentophilic granules. These characteristics and the overall shape of the denticles suggested a species determination as 


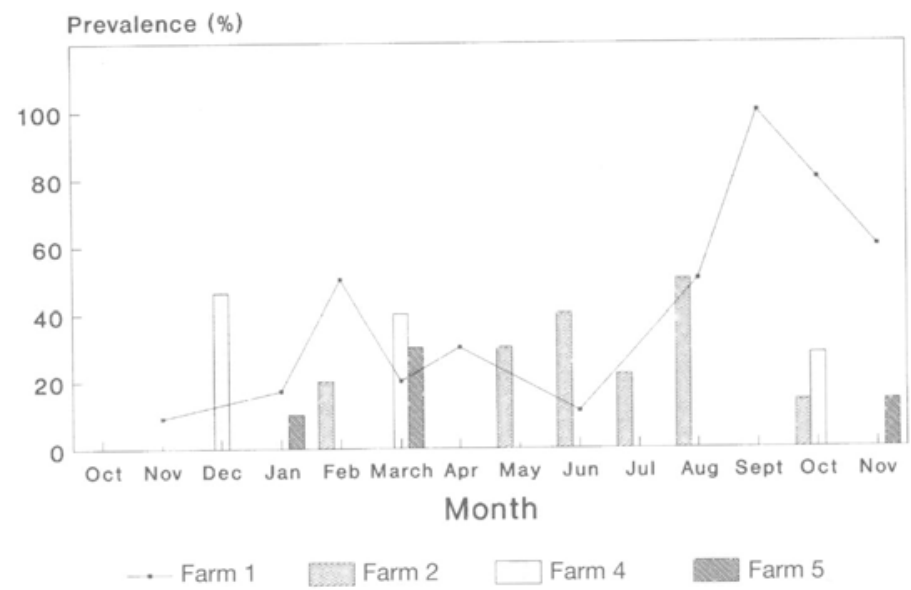

Figure 5. Seasonal variation of prevalence of infection of Hexamita salmonis in 5 Danish trout farms from October 1993 to November 1994.

T. fultoni. On the gills of trout from Farm 5, the small (adhesive disc diameter $25 \mu \mathrm{m}$ ) Trichodinella epizootica was recovered.

\section{Discussion \\ Monogeneans}

The 2 monogenean species found in this study - Gyrodactylus derjavini and G. salaris - are known parasites from rainbow trout (Mo 1991, Malmberg 1993, Buchmann et al. 1995). These have been found in Danish trout farms previously. In an early study (Malmberg 1973), 2 different species of Gyrodactylus parasitizing rainbow trout in Denmark (in Brøns and in Kolding, respectively) were reported. Later studies on the material have clarified that these parasites were $G$. derjavini and $G$. salaris (Malmberg \& Malmberg 1987, Malmberg 1993).

Gyrodactylus derjavini infections of trout in Denmark require treatment and are occasionally treated with formaldehyde (Malmberg 1993) which indicates a pathological effect of the parasite. In contrast the congener $G$. salaris does not seem to elicit mortality in infected rainbow trout under experimental laboratory conditions (Bakke et al. 1991). Races of brown trout (Salmo trutta) were reported by Ergens (1983) to be severely affected by $G$. derjavini infections. However, no controlled experiments have yet been conducted to elucidate the effect of $G$. derjavini or the Danish isolated strain of $G$. salaris on the Danish rainbow trout populations. Such studies together with detailed pathology investigations (Cone \& Odense 1984) should be performed prior to any conclusions on the pathology of monogeneans in the Danish trout enterprises. Thus the genetic outfit of both the host and the monogenean parasite are of major importance in such questions (Madhavi \& Anderson 1985).

The Norwegian feral strains of Salmo salar have been seriously reduced due to the infections with the G. salaris imported from Sweden (Johnsen \& Jensen 1988, Malmberg 1993). Like the Norwegian salmon, also the Scottish 


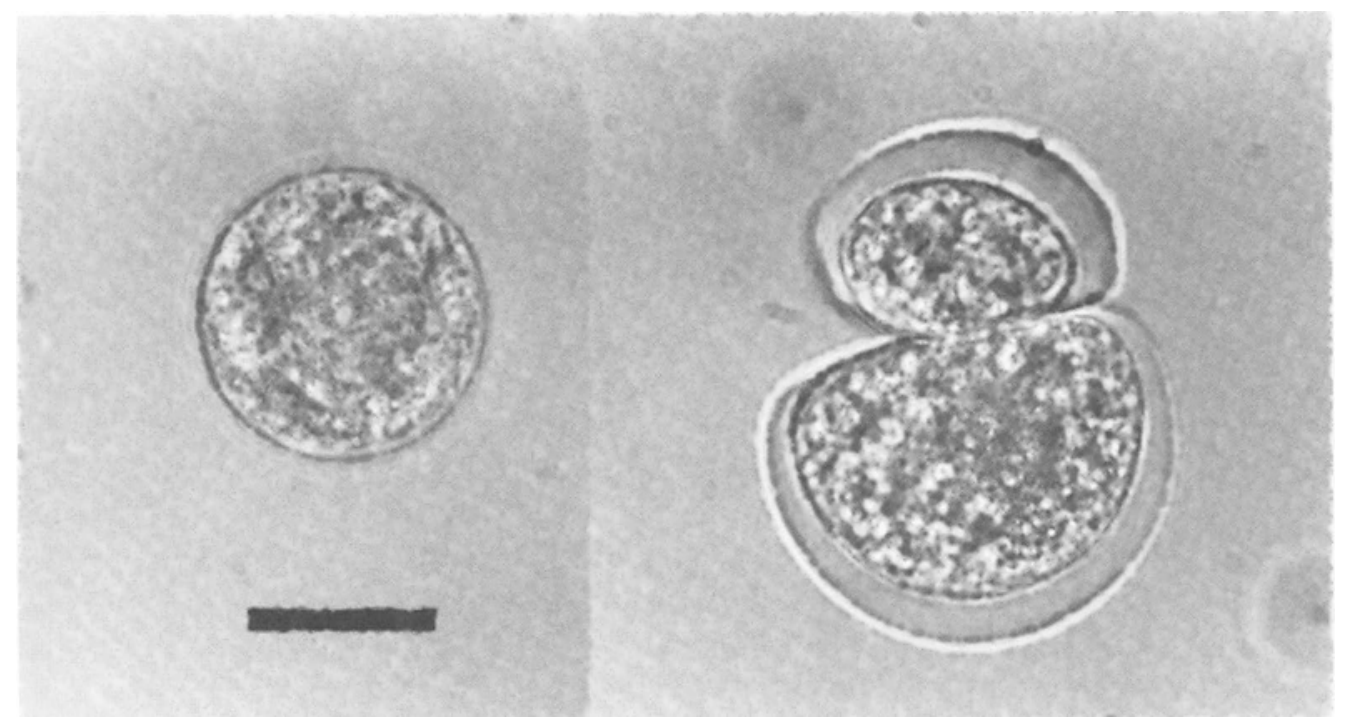

Figure 6. Ichthyophonus like unicellular intestinal organism. Dividing form at the right. Scale bar: $20 \mu \mathrm{m}$.

salmon is extremely susceptible to this monogenean (Bakke \& MacKenzie 1993). In contrast the Baltic Neva strain of the same host species are relatively resistant to this parasite (Bakke et al. 1990). Before any conclusions are drawn on the importance of $G$. salaris infections of Danish rainbow trout for the spread of the parasite to different salmon stocks, controlled experiments should elucidate the effect of the isolated Danish strain of G. salaris on various strains of Salmo salar.

\section{Cestodes}

Only 1 farm (which received natural lake water) was found infected with cestodes. $E u$ bothrium crassum, Proteocephalus sp. (juvenile) and Triaenophorus nodulosus were found in low graded infections in autumn and winter. Cestodes of these genera are known pathogens of salmonids (Bauer \& Solomatova 1984, Engelhardt et al. 1988, Berland 1991). However, the very low infection level found in the Danish farm is probably of minor impor- tance. Cestodes of the genus Proteocephalus in Danish trouts were previously reported by From \& Horlyck (1981) and later identified by Hanzelova \& Scholz (1992) as Proteocephalus neglectus. This paper is the first record of Triaenophorus nodulosus in Denmark. This cestode has pike (Esox lucius) as final host, and the life cycle of this parasite probably occurs in the natural lake connected to the farm. Eubothrium crassum is a well known parasite of rainbow trout (Wootten 1972, Buchmann et al. 1995) and was found in Salmo trutta in Denmark (Buchmann 1987). However, this is the first report of this cestode in Danish rainbow trout. Whether trout in this farm are infected through ingestion of copepods acting as intermediate hosts or due to eating transport hosts like sticklebacks ( 2 possible infection routes indicated by Vik (1963)) is not yet known. However, the infected farm received water from a natural lake and it is supposed that infective stages in intermediate hosts (copepods) entered the farm via the inlet water. 


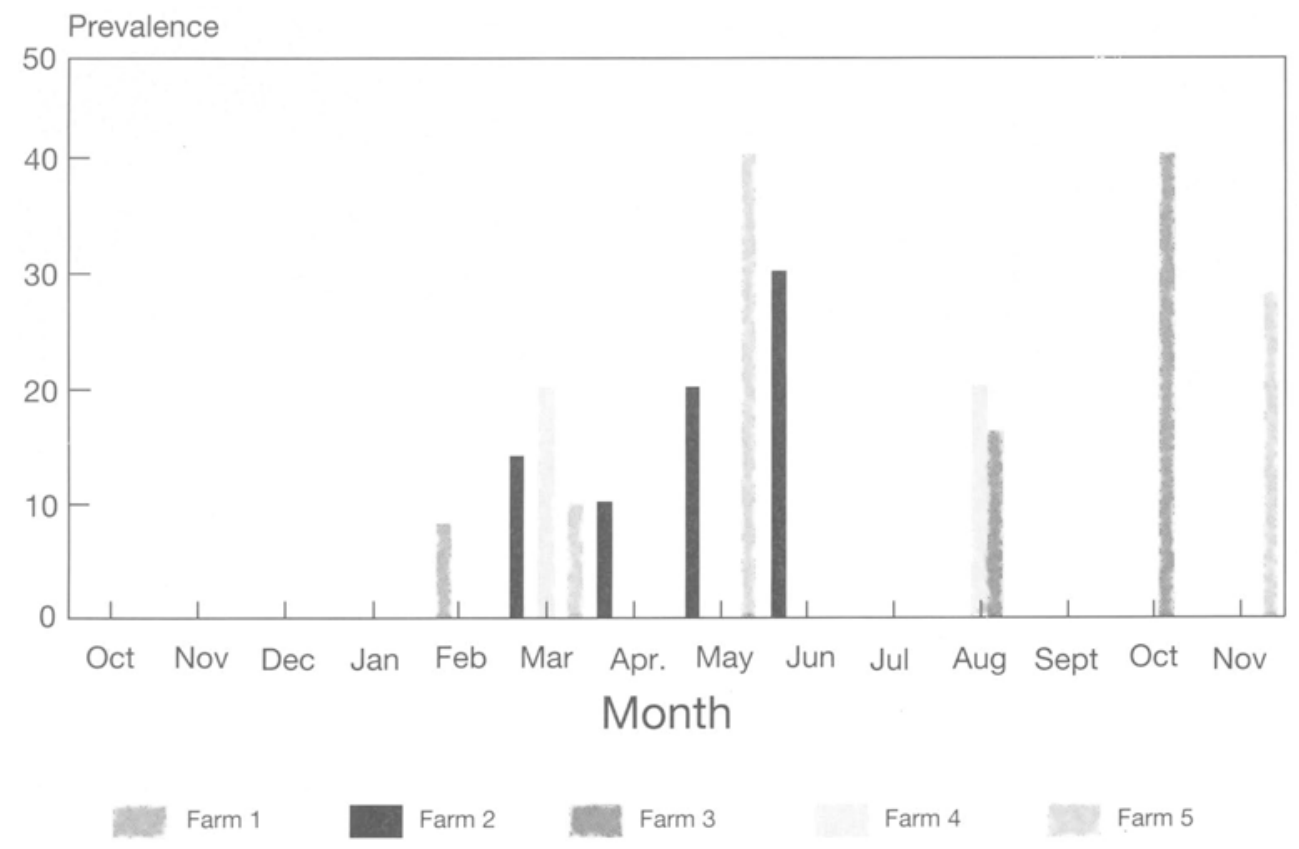

Figure 7. Prevalence of the intestinal unicellular Ichthyophonus like organism during the 1 year investigation period.

\section{Digenean trematodes}

The only digeneans detected in the present study were metacercarial stages of Diplostomum spathaceum (located in the lens) and Tylodelphus clavata (located in the vitreous humour). The lens metacercariae were all determined as $D$. spathaceum according to criteria provided by Höglund \& Thulin (1992). One farm was found notably infected, another very lightly infected ( $D$. spathaceum only) and the remaining 3 farms were not infected at all. $D i$ plostomum infections have been well studied in trout farms (Stables \& Chappell 1986 a) and the infection is connected to the presence of infected intermediate hosts (pulmonate snails) in the ponds. A total of 151 snails (116 Lymnaea pereger and 35 L. stagnalis) were collected in the infected trout farm (Farm 3). Of these were $3.4 \%$ and $2.9 \%$, respectively, found to release furcocercariae. These were experimentally shown to penetrate rainbow trout skin and migrate to the eye lens for development into Diplostomum spathaceum metacercariae (data not shown). The release of Diplostomum spathaceum cercariae from the snails is known to decrease significantly at lower temperatures (Sous 1992). Pronounced reduction at low temperatures of Diplostomum spathaceum cercarial shedding from Lymnaea pereger and L. stagnalis collected in Farm 3 has actually been demonstrated (data not shown). In addition the migration in the host of diplostomules after penetration of the host skin is also inhibited (Stables \& Chappell 

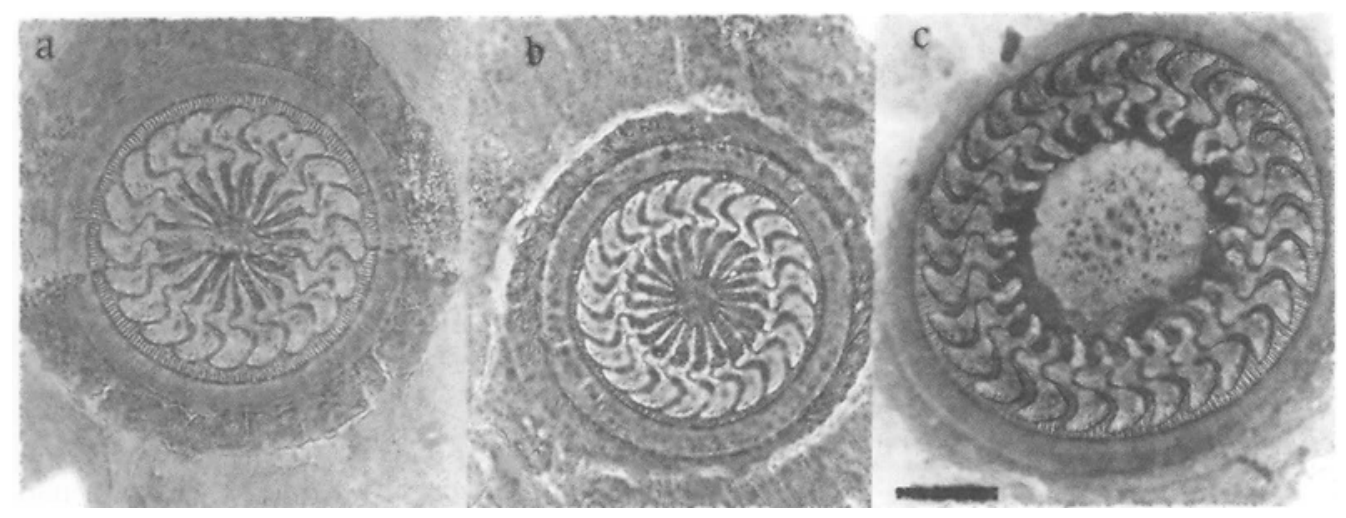

Figure 8. Micrographs of a) Trichodina nigra, b) T. mutabilis and c) T. fultoni from Danish rainbow trout farms.Scale bar: $20 \mu \mathrm{m}$.

1986 b). This will explain the observed decrease in prevalence of infection during winter and early spring. Uninfected fish introduced into the farm during that season (which is common practice) are exposed to a reduced infection pressure which will result in the observed decrease in farm infection. The infection with Tylodelphus clavata was very low and is probably of minor importance. Diplostomum metacercariae located in the lens of rainbow trout have been shown to cause cataract (Shariff et al. 1980), affect growth of the host (Sato et al. 1976, Buchmann \& Uldal 1994) and even elicit mortality of smaller hosts (Brassard et al. 1982). Thus it is possible that the infection in Farm 3 will influence the fish production.

\section{Crustaceans}

The branchiuran Argulus foliaceus was only detected once in 1 farm (Farm 3) receiving lake water to the ponds. Therefore it is likely that larval stages enter the farm with inlet water from the natural lake. This parasite is a serious pathogen in fish farming enterprises (Bauer et al. 1973) but has not been reported frequently from the rainbow trout (Kennedy
1974, Buchmann et al. 1995) and never before from Danish rainbow trout. The situation in the present farm should be followed, as Oncorhynchus mykiss seems to be quite susceptible to infection. Thus devastating infections with Argulus foliaceus on rainbow trout (several hundred specimens per host) were found in a put and take lake (stocked with trout for angling purposes) on the Danish island of Bornholm in the Baltic in August 1992 (Buchmann, unpublished).

The salmon lice, Lepeophtheirus salmonis and Caligus elongatus, are well known pathogens in cage rearing of salmonids (Wootten et al. 1982) and the finding of these crustaceans suggests that parasite investigations on rainbow trout in net cage rearing enterprises should be reinforced.

Intestinal trematodes, nematodes and acanthocephalans were not found in rainbow trout in the present investigation although some of these groups are quite common in feral trout in Denmark (Buchmann 1989). This lack of parasites which demand ingestion of intermediate hosts as insect larvae or crustaceans corresponds to the sparcity of similar parasites in cultured salmon (Wootten \& Smith 1980). It 
can be explained by the sparce and unvaried fauna in intensive trout ponds whereby appropriate intermediate host are lacking. Previously, marine nematodes occurred in Danish freshwater trout (Christensen \& From 1978) due to feeding with marine fish offals containing nematode larvae. As this practice is presently prohibited and trout exclusively are fed with pelleted dry feed the Danish trout should be considered free from anisakid nematodes.

\section{Protozoans}

Hexamita salmonis. The intestinal diplomonadid flagellate Hexamita salmonis was early recognized as a serious pathogen in salmonids (Moore 1925). However, the pathogenicity of the protozoan to some salmonids was later disputed by Uzman et al. (1965) although these authors found a negative effect on the rainbow trout health of experimental infections. In our study we registered considerable fry mortality in the most heavily Hexamita infected farm (Farm 1) and experiments are in progress for evaluation of the pathogenicity of the Danish parasite strain to the Danish rainbow trout.

Hexamita salmonis has previously been reported from European rainbow trout farms (Christensen et al. 1963, Zitnan \& Cankovic 1970, Ferguson 1979, Rosengarten 1985, Poynton \& Bennett 1985, Poynton 1986). We found that mostly fry and smaller fingerlings are infected which is in accordance with Rosengarten (1985) and Poynton (1986). The presence of the parasite in all seasons suggests that Hexamita salmonis has a wide temperature amplitude for reproduction although this has not been experimentally demonstrated. The location of this flagellate along the entire length of the fry intestine in heavily infected fish is worth noting. That this location is due to some intraspecific competition is indicated as lightly infected fish harboured higher flag- ellate numbers in the anterior part of the intestine. However, already Moore (1925) stated that this part is preferably infected in the earliest state of the infection whereafter the parasite spreads to the rest of the intestine.

Ichthyobodo necator. The ectoparasitic kinetoplastid flagellate occurred infrequently on the exterior part of the trout. Although this parasite is a known pathogen of salmonids eliciting host mortality (Christensen et al. 1963, Robertson 1979) the low infection found in the present study did not allow a closer analysis.

Ichthyophthirius multifiliis. Trophonts of this ciliate producing white spot disease in fish (Bauer et al. 1973) occurred sporadically and was associated with fry morbidity and mortality in Farm 4 (fish farmers information). Larger fish were found to harbour few specimens without showing signs of weakness. This might be explained by manifestations in the fishes of resistance mechanisms to this ciliate (Hines \& Spira 1974). However, the frequent use of chloramine, formaldehyde and copper sulphate in the ponds may have influenced the parasite abundance.

The trichodinids Trichodina nigra, T. mutabilis and T. fultoni and sessile ciliates as Apiosoma sp. and Epistylis sp. occurred throughout the year but not as abundantly as similar ciliate types reported by Wootten \& Smith (1980) in salmon hatcheries. This might be due to the frequent use of chloramine, formaldehyde and copper sulphate in the farms. The effect of these parasites on the Danish trout production is not yet clear.

PKX. The low prevalence and sporadic occurrence of this parasite in the examined farms was only detected by the lectin-binding technique on smears and further studies should evaluate the reliability of this technique. PKX was recorded for the first time in 
Denmark in 1982 (Olesen 1985) and the infection is considered a serious obstacle to trout farming (Clifton-Hadley et al. 1984, Hedrick 1993). However, the impact of this parasite on the trout production in the examined Danish trout farms is not clear.

The fungus like organism with an Ichthyophonus-like appearance recorded in the intestines of fish from the Danish trout farms call for further investigations. Their taxonomy, life cycle and possible pathogenicity has not yet been elucidated. However, a similarity was found to certain stages of Ichthyophonus hoferi cultivated by Okamoto et al. (1985). In vitro cultivation of these recovered parasites should be implemented and compared to the Japanese studies.

\section{Conclusions}

The number of trout farms in Denmark is exceeding 400 . Therefore this report on parasites in Danish trout-rearing enterprises is not claiming to be representative of all Danish farms. Other parasite types might be found during extended surveys in Danish trout farms. Also the time delay between collection of fish and examination may influence the results. However, a number of parasite problems have been pinpointed. Of these infections with the monogeneans Gyrodactylus derjavini and G. salaris warrant detailed studies on population biology and pathology in different salmonid hosts. The diplostomid trematode infections are prevalent at least in some farms and require further research on prophylaxis and treatment. The intestinal flagellate Hexamita salmonis is often found associated with fry mortality and morbidity. Future experiments should elucidate the possible pathogenicity of this parasite and provide prophylactic measures. The detection, epidemiology and importance of PKD in Danish trout farms should, due to its possible pathogenicity, be followed during the following years. Also Ichthyophthirius multifiliis is a known pathogen and requires studies on prophylaxis and treatment. The record of the salmon lice in Danish mariculture systems calls for further investigations of parasite infections in those enterprises.

\section{Acknowledgements}

This work was supported by the Danish Agricultural and Veterinary Research Council and is a part of the Danish programme on Disease prevention, genetics and nutrition in rainbow trout production. The authors are indebted to Steen Møller (National Institute of Animal Science, Tjele), Jon From (Inland Fisheries Laboratory, Silkeborg), Viggo Hørlyck, Christian Graver, Per Aarup (Danish Trout Culture Research Station, Brøns) and T. Nielsen (Brande), who collected a considerable number of the examined fishes. Sincere thanks go to Dr. Göran Malmberg (University of Stockholm) who kindly guided K. Buchmann into the Gyrodactylus taxonomy and determined or verified our determination of Gyrodactylus species. The cooperation of Dr. Ken MacKenzie (Marine Laboratory, Aberdeen) is likewise appreciated. Dr. N.J. Olesen (National Veterinary Laboratory, Århus) provided instructions on the modified lectin binding assay.

\section{References}

Bakke TA, MacKenzie K: Comparative susceptibility of native Scottish and Norwegian stocks of Atlantic Salmon, Salmo salar L., to Gyrodactylus salaris Malmberg: Laboratory experiments. Fish. Res. 1993, 17, 69-85.

Bakke TA, Jansen PA, Hansen LP: Differences in the host resistance of Atlantic salmon, Salmo salar L., stocks to the monogenean Gyrodactylus salaris Malmberg, 1957. J. Fish Biol. 1990, 37, 577-587.

Bakke TA, Janssen PA, Kennedy CR: The host specificity of Gyrodactylus salaris Malmberg (Platyhelminthes, Monogenea): susceptibility of Oncorhynchus mykiss (Walbaum) under experimental conditions. J. Fish Biol. 1991, 39, 45-57.

Bauer ON, Solomatova VP: The cestode Trianophorus crassus (Pallas) (Pseudophyllidea: Triaenophoridae) as a pathogen of cage-reared salmonids. J. Fish Dis. 1984, 7, 501-504. 
Bauer ON, Musselius VA, Strelkov Yu A: Bolezni Prudovykh ryb. Izdatel stro »Kolos« Moskva 1969. (Diseases of pond fishes). Israel program for scientific translations, Jerusalem 1973.

Berland B: Cestoda, Bendelmark. (Cestodes, tapeworms). In: Poppe TT (Ed) Fiskehelse (Fish Health). John Grieg Forlag 1991.

Buchmann K: Cestodes of migratory trout (Salmo trutta L.) from the Baltic Sea. Bull. Eur. Ass. Fish Pathol. 1987, 7, 115-117.

Buchmann K: Trematodes and acanthocephalans of Salmo trutta from the Baltic sea. Bull. Eur. Ass. Fish Pathol. 1989, 9, 9-11.

Buchmann K, Uldal A: Effects of eyefluke infections on growth of rainbow trout (Oncorhynchus mykiss) in a mariculture system. Bull. Eur. Ass. Fish Pathol. 1994, 14, 104-107.

Buchmann K, Uldal A, Lyholt HCK: A checklist of rainbow trout metazoan parasites. Acta vet. scand. 1995, 36, 295-314.

Brassard P, Rau ME, Curtis MA: Infection dynamics of Diplostomum spathaceum cercariae and parasite-induced mortality of fish host. Parasitology 1982, 85, 489-493.

Christensen NO, Jensen M, Rasmussen CI: Fish diseases in Denmark. Bull. Off. int. Epiz. 1963, 59, 21-29.

Christensen S, From J: Rundorme og deres bekæmpelse hos dambrugsfisk. (Roundworms and their eradicaton in farmed fish). Ferskvandsfiskeribladet 1978, 8, 94-100.

Clifton-Hadley RS, Bucke D, Richards RH: Proliferative kidney disease of salmonid fish: a review. J. Fish Dis. 1984, 7, 363-377.

Cone DK, Odense PH: Pathology of 5 species of $G y$ rodactylus Nordmann, 1832 (Monogenea). Can. J. Zool. 1984, 62, 1084-1088.

Engelhardt A, Mirle C, Granitza I, Petermann $H$ : Untersuchungen zum Vorkommen, zur Schadwirkung und Bekämpfung von Proteocephalus neglectus bei Regenbogenforellen in der Netzkäfighalten. (An investigation into the the occurrence, pathology and control of Proteocephalus neglectus infections in rainbow trout in net cages). Monatshefte für Veterinärmedizin 1988, 43, 169-172.

Ergens R: Gyrodactylus from Eurasian freshwater Salmonidae and Thymallidae. Folia Parasitol. 1983, 30, 15-26

Ferguson HW: Scanning and transmission electron microscopical observations on Hexamita salmonis (Moore, 1922) related to mortalities in rain- bow trout fry Salmo gairdneri Richardson. J. Fish Dis. 1979, 2, 57-67.

From J, Hørlyck V: First recorded occurrence of Proteocephalus percae (Müller, 1780) in Danish farmed trout. Bull. Eur. Ass. Fish Pathol. 1981, 1, 40-41.

Hanzelova V, Scholz T: Redescription of Proteocephalus neglectus La Rue, 1911 (Cestoda: Proteocephalidae), a trout parasite, including designation of its lectotype. Folia Parasitol. 1992, 39, 317-323.

Hare GM, Frantsi C: Abundance and potential pathology of parasites infecting salmonids in Canadian maritime hatcheries. J. Fish Res. Board Canada 1974, 31, 1031-1036.

Hedrick RP, MacConnell E, de Kinkelin, P: Proliferative kidney disease of salmonid fish. Annual Rev. Fish Dis. 1993, 277-290.

Hedrick RP, Marin M, Castagnaro M, Monge D, de Kinkelin P: Rapid lectin based staining procedure for the detection of the myxosporean causing proliferative kidney disease in salmonid fish. Dis. aquat. Org. 1992, 13, 129-132.

Hines RS, Spira DT: Ichthyophthiriasis in the mirror carp Cyprinus carpio (L.) V. Vet. J. Fish Biol. 1974, 6, 373-378.

Höglund, J., Thulin, J.: Identification of Diplostomum spp. in the retina of perch Perca fluviatilis and the lens of roach Rutilus rutilus from the Baltic Sea - an experimental study. Syst. Parasitol. 1992, 21, 1-19.

Johnsen BO, Jensen AJ: Introduction and establishment of Gyrodactylus salaris Malmberg, 1957, on Atlantic salmon, Salmo salar L., fry and parr in the River Vefsna, northern Norway. J. Fish Dis. 1988, 11, 35-45.

Kennedy CR: A checklist of British and Irish freshwater fish parasites with notes on their distribution. J. Fish Biol. 1974, 6, 613-644.

Lom J, Dykova I: Protozoan parasites of fishes. Developments in aquaculture and fisheries science, Elsevier. 1992, 26, 1-315.

Madhavi R, Anderson RM: Variability in the susceptibility of the fish host Poecilia reticulata to infection with Gyrodactylus bullatarudis. Parasitology 1985, 91, 531-544.

Malmberg G: Om forekomsten af Gyrodactylus på svenske fisk (On the occurrence of Gyrodactylus on Swedish fishes). Skr. södr. Sver. Fisk. För. Årsskr. 1957, 1956, 19-76.

Malmberg G: Gyrodactylus infestations on species of Salmo in Danish and Swedish hatcheries. Norw. 
J. Zool. 1973, 21, 325-326.

Malmberg G: Gyrodactylidae and gyrodactylosis of salmonidae. Bull. Fr. Peche Piscic. 1993, 328, 546.

Malmberg G, Malmberg M: Gyrodactylus in salmon and rainbow trout farms. In: Stenmark A, Malmberg G (Eds): Parasites and diseases in natural waters and aquaculture in Nordic countries. Naturhistoriska Riksmuseets Reprocentral, Stockholm. 1987, 199-204.

McGuigan JB, Sommerville C: Studies on the effects of cage culture of fish on the parasite fauna in a lowland freshwater loch in the west of Scotland. Z. Parasitenk. 1985, 71, 673-682.

Mo TA: Variations of opisthaptoral hard parts of $G y$ rodactylus salaris Malmberg, 1957 (Monogenea: Gyrodactylidae) on rainbow trout Oncorhynchus mykiss (Walbaum, 1792) in a fish farm, with comments on the spreading of the parasite in south-eastern Norway. Syst. Parasitol. 1991, 20, 1-9.

Moore E: Octomitus salmonis, a new species of intestinal parasite in trout. Trans. Amer. Fish. Soc. 1925, 54, 74-93.

Olesen NJ: PKD i 1984 (PKD in 1984). Ferskvandsfiskeribladet 1985, 5, 126-129.

Okamoto N, Nakase K, Suzuki H, Nakai Y, Fujii K, Sano T: Life history and morphology of Ichthyophonus hoferi in vitro. Fish Pathol. 1985, 20, 273285.

Poynton SL: Distribution of the flagellate Hexamita salmonis Moore, 1922 and the microsporidian Loma salmonae Putz, Hoffman and Dunbar, 1965 in brown trout, Salmo trutta L., and rainbow trout, Salmo gairdneri Richardson, in the River Itchen (U.K.) and 3 of its fish farms. J. Fish Biol. 1986, 29, 417-429.

Poynton SL, Bennett CE: Parasitic infections and their interactions in wild and cultured brown trout and rainbow trout from the river Itchen, Hampshire. In: Ellis AE (ed): Fish and Shellfish Pathology. Academic Press, London. 1985, 353357.

Robertson DA: Host parasite interactions between Ichthyobodo necator (Henneguy, 1883) and farmed salmonids. J. Fish Dis. 1979, 2, 481-491.

Rosengarten R: Parasitologische Untersuchungen an Regenbogenforellen (Salmo gairdneri Richardson) in einer Forellenteichwirtschaft in Niedersachsen. (Parasitological investigations on rainbow trout (Salmo gairdneri Richardson) in a trout farm in Niedersachsen) Dissertation. Fach- gebiet Fischkrankheiten und Fischhaltung der Tierärztlichen Hochschule Hannover, Germany 1985.

Sato T, Hoshina T, Horiuchi M: On worm cataract of rainbow trout in Japan. Bull. Jap. Soc. Sci. Fish. 1976, 42, 249.

Shariff $M$, Richards RH, Sommerville C: The histopathology of acute and chronic infections of rainbow trout, Salmo gairdneri Richardson with eye flukes, Diplostomum spp. J. Fish Dis. 1980, 3, 455-465.

Sous SM: Influence of abiotic factors on emission and survival of cercariae of Diplostomum chromatophorus (Brown, 1931) (Trematoda, Diplostomidae). Ecol. Parasitol. 1992, 1, 154-159.

Stables JN, Chappell LH a: The epidemiology of diplostomosis in farmed rainbow trout from northeast Scotland. Parasitology 1986, 92, 699-710.

Stables JN, Chappell LH b: Diplostomum spathaceum (Rud. 1819): Effects of physical factors on the infection of rainbow trout (Salmo gairdneri) by cercariae. Parasitology 1986, 93, 71-79.

Uzmann JR, Paulik GJ, Hayduk SH: Experimental hexamitiasis in juvenile coho salmon (Oncorhynchus kisutch) and steelhead trout (Salmo gairdneri). Trans. Amer. Fish. Soc. 1965, 94, 53-61.

Vik R: Studies of the helminth fauna of Norway. IV. Occurrence and distribution of Eubothrium crassum (Bloch, 1779) and E. salvelini (Schrank, 1790) (Cestoda) in Norway, with notes on their life cycles. Nyt Mag. Zool. 1963, 11, 47-73.

Wootten R: Occurrence of Eubothrium crassum (Bloch, 1779) (Cestoda: Pseudophyllidea) in brown trout, Salmo trutta L., and rainbow trout, S. gairdneri Richardson, 1836, from Hanningfield Reservoir, Essex. J. Helminthol. 1972, 46, 327-339.

Wootten R, Smith JW: Studies on the parasite fauna of juvenile Atlantic salmon, Salmo salar L., cultured in fresh water in eastern Scotland. Z. Parasitenk. 1980, 63, 221-231.

Wootten R, Smith JW, Needham EA: Aspects of the biology of the parasitic copepods Lepeophtheirus salmonis and Caligus elongatus on farmed salmonids, and their treatment. Proc. Royal Soc. Edingb. (B) 1982, 81, 185-197.

Zitnan R, Cankovic M: Comparison of the epizootological importance of the parasites of Salmo gairdneri irideus in the 2 coast areas of Bosna and Herzegovina. Helminthologia 1970, 11, 161-166. 


\section{Sammendrag \\ Parasitinfektioner i danske фrredbrug.}

Regnbue $\varnothing$ rreder fra 5 danske ferskvandsdambrug er blevet underkastet en parasitologisk undersøgelse fra oktober 1993 til november 1994. Desuden er ektoparasitter fra et havbrugssystem med regnbue$\emptyset$ rreder blevet registreret. Ved unders $\emptyset$ gelsen er der blevet fundet 10 arter af flercellede snyltere samt 10 encellede snyltere. De flercellede omfatter monogenerne Gyrodactylus salaris og $G$. derjavini, cesto- derne Eubothrium crassum, Proteocephalus sp., Triaenophorus nodulosus, trematoderne Diplostomum spathaceum og Tylodelphus clavata, krebsdyrene Argulus foliaceus, Lepeophtheirus salmonis og Caligus elongatus.

De encellede parasitter omfatter Hexamita salmonis, Ichthyobodo necator, Ichthyophthirius multifiliis, Apiosoma sp., Epistylis sp., Trichodina nigra, T. mutabilis, T. fultoni, Trichodinella epizootica og PKX. Desuden er der i enkelte regnbueørreders tarm registreret en Ichthyophonus lignende organisme.

(Received November 30, 1994; accepted April 29, 1995).

Reprints may be obtained from: K. Buchmann, Department of Veterinary Microbiology, Section of Fish Diseases, Royal Veterinary and Agricultural University, 13 Bülowsvej, DK-1870 Frederiksberg C, Denmark. 